\title{
Influence of Microfinance Bank Products Accessibility on Small Scale Enterprises Performance
}

\author{
Odetayo, T.A. Ph.D ${ }^{1}$ and Onaolapo, A.R. Ph.D ${ }^{2}$ \\ ${ }^{l}$ Department of Accountancy, Osun State Polytechnic, Iree, Nigeria
${ }^{2}$ Department of Accounting and management, Ladoke Akintola University of Technology, Ogbomoso, Nigeria
}

\begin{abstract}
This study examined the influence of the Microfinance bank products accessibility on Small scale enterprises (SSEs) in Osun State, Nigeria. Descriptive survey research design was adopted for this study. The population for the study comprised all microfinance banks and small scale enterprises in Osun State. Thirty (30) MFBs were purposively sampled and For Hundred and Fifty (450) SSEs were randomly sampled. Two sets of questionnaires designed to collect data were tested for reliability using Cronbach's alpha: QMFB ( $\mathrm{r}=$ $0.89)$ and QSSEs $(r=0.70)$. Data were analysed using tables, frequencies as well as simple percentages while multiple regressions were used to test hypotheses one and two at 0.05 level of significance. Degree of accessibility to MFB products was measured using savings account (92\%), current account $(54.2 \%)$ and business loan $(52.3 \%)$. A regression analysis designed to examine the influence of MFB products accessibility on SSEs' performance revealed that MFB products accessibility perception jointly predicted changes in SSEs total capital given $\mathrm{F}_{(8,318)}=17.936$; number of employees $\mathrm{F}_{(8,318)}=4.136$; sales $\mathrm{F}_{(8,318)}=15.316$; and profit $\mathrm{F}_{(8,318)}=15,699$; all values being significant at 0.05 level. In conclusion, activities of MFBs impacted on the SSEs in the study area given the predicted values of financial product accessibility on sales and profit but with a limited effect on total capital and number of employees engaged.
\end{abstract}

Key Words: Nigeria, microfinance, enterprises performance

\section{Introduction}

Small Scale Enterprises (SSEs) can be described as the 'live wire' of a developing economy like Nigeria. In many economies of the world, there are only few large enterprises, whereas small scale enterprises dominate the economic landscape of most countries (Tarmidi, 2005; Benzing and Chu, 2009 and Kessy and Temu, 2010 cited in Akande, 2012). In Nigeria, there are currently over 17 million $\mathrm{Mi}$ cro, Small and Medium enterprises in the country which engage over 31 million Nigerians which represents a significant proportion of the populace (Aganga, 2012). However, small scale enterprises are characterised by low business performance as evident in low sales revenue, fewer assets, smaller profit margins and lower likelihood of survival and this is caused by factors such as lack of credit, saving, education or training and social capital which affect entrepreneurial performance (Shane, 2003 and Akanji, 2006). Out of all these problems, inadequate funding has been identified as a significant impediment facing small scale enterprises in Nigeria, Osun State inclusive (Oboh, 2005).

The introduction of microfinance banking in most developing economies like Nigeria was borne out of the need to bring financial services nearer to the people, particularly the low income earners given the inaccessibility of such services from conventional banks. Microfinance services refer main- ly to small loans; saving mobilization and training in micro enterprise investment services extended to poor people to enable them undertake selfemployment projects that generate income (Ondoro and Omena, 2012). They argued that microfinance services include savings, credit, payment facilities, remittances and insurance. Non-financial services mainly entail training in micro enterprise investment and business skills.

Yahaya et al., (2011) opined that financial services needed by the entrpreneurs include working capital loans, consumer credit, savings, pension insurance and money transfer services. Jegede, Kehinde and Akinlabi (2011) investigated the relationship between microfinance loan disbursement and poverty alleviation in Nigeria. They employed the use of Chi square, F-test and T-test. The study found that there was a significant difference between those people who used microfinance institutions and those who do not use them.

Corresponding author: Odetayo, T.A. Ph.D., Department of Accounting and management, Ladoke Akintola University of Technology, Ogbomoso, Nigeria. Email: deentao@yahoo.com

(c) This article is distributed under the terms of the Creative Commons Attribution License, which permits unrestricted use and redistribution provided that the original author and source are credited. 
Research Questions: (i) What are the financial products specifically developed by Nigerian microfinance banks for Small Scale Enterprises (SSEs)? (ii) How accessible are the Microfinance Banks' credit facilities to Small Scale Enterprises?

\section{Research Objectives}

The study was designed to : (i) examine the types of financial products made available by microfinance banks and rendered to small scale enterprises in the study area; (ii) investigate the degree of accessibility of microfinance bank financial products by small scale enterprises (iii) determine the influence of microfinance banks financial products accessibility on small scale enterprises performance'

\section{Scope of the study}

The geographical scope of the study covered microfinance banks and small scale enterprises in Osun State. The content scope of the study covered influence of microfinance bank management staff activities in financing small scale enterprises. Variable of interest include microfinance bank MFB financial products as independent variables. SSEs profits, SSEs total capital, SSEs sales and number of employees as dependent variables

\section{Literature Review}

\section{Analyses of Financial Performances of Small Scale Enterprises (SSEs)}

The performances of SSEs were based largely on perception of the impact of MFBs on the following four assessments, namely total capital, number of employees, turnover and profit. Asaolu (2004) in his study found that majority $(79 \%)$ of SSE surveyed started business with a capital base of less than a million naira and about $85 \%$ and $33 \%$ of the CICS financed and non financed enterprises had capital base greater than $\$ 1$ million respectively, meaning that the better performance of the CICS financed enterprises might be due to their access to cooperative loans.

Considering performance by the index of profits, Asaolu (2004) found that majority (69\%) of the CICS financed enterprises moved from a profit level of $\$ 2,000,000$ and below to $\$ 2,000,000$ and above. According to Asaolu (2004), the reason for this could be that the cheaper source of funding to the CICS financed SSEs had assisted in increasing their capital bases and enhanced their profitability unlike their non-CICS financed counterparts. Asaolu (2004)'s study also revealed that there was a positive relationship between SSEs profit levels and their utilization of CICS loans $(\mathrm{r}=0.75, \mathrm{p}<$ 0.47). Asaolu (2004) found that CICS-financed
SSEs employed more people than the non-CICS financed counterpart. He opined that this may probably be attributable to the fact that the later had access to funds from CICS, which enhanced their scale of operations, which necessitated, and increased employment. Asaolu (2004) also found a positive relationship of $\mathrm{r}=0.95$ and $\mathrm{p}<0.58$ between CICS loan utilization and level of employment.

\section{Accessibility of Small Scale Enterprises to MFB Finance}

Microfinance bank as an engine of economic growth can differentiate themselves from their competitors through their inclusion strategies of access to finance especially by the poor and vulnerable groups (Onaolapo and Odetayo, 2012).

The loan sizes accessed by poor households or SSEs were a big issue in Coleman's (2006) study; Coleman (2006) argued that loan sizes were too small to make any significant difference in household welfare. The size of loans even prompted some women to leave the microfinance programmes arguing that loans were too small for any meaningful income generating activity. Coleman (2006) argued that one reason why wealthier borrowers may have experienced larger impacts was because they could command larger loans. Yahaya et al (2011) opined that for microfinance banks to play its role in the economy, regulatory and other statutory bodies should monitor the interest rate on loans and advances to make it accessible to microclients that are the economically active poor. Access to microfinance enables the poor to create, own and accumulate assets and smooth consumption. Jamil (2008) opined that micro entrepreneurs and low income earners are denied accesses to financial services on account of their inability to provide tangible asset as collateral for credits.

\section{Accessibility of Small Scale Enterprises to Gen- eral Banking Services}

Banerjee, Duflo and Kinnan, (2010) have documented the fact that a huge proportion of the poor still lack access to formal banking services. Gaul (2011) calculated the absolute difference between the population living below the poverty line and the population with access to financial services, and found that the numbers are as high as 80 million for Nigeria and 48 million for Congo. In a related development, literature substantiate the fact that women entrepreneurs, especially in developing countries do not have easy access to credit for their entrepreneurial activities (Ibru, 2009; Okpukpara, 2009; Iganiga, 2008; Kuzilwa, 2005 and Iheduru, 2002) whereas the rate of women participation in the internal sector of the economy is largely higher than males (Akanji, 2006 and Akiniyi,2009). 
Gulani and Usman (2014) opined that the inability of the poor to access credit for SSEs financing makes them unable to undertake profitable investments and hence remain poor. If this could be checked however, the greatest challenge of SSEs will be removed. Gulani and Usman (2014) found that personal savings have the highest total number of responses with 32 out of 65 analysed and concluded that personal saving is the most accessible sources of finance to SSEs in Gombe State of Nigeria. They submitted that banks and MFIs are not within the reach of the MSEs and the SSEs fall back on personal savings, and family and friends to meet their finance needs. Their finding reiterates earlier submissions of Nkamnebe (2008) that entrepreneurs look for credit from other sources like friends and tribal association than from MFIs. Further, Oni, Paiko and Ormin (2012) also reported that access to MFI services by SMEs is poor.

On accessibility of Nigerian banks, the CBN pointed out that only $35 \%$ of Nigerians had access to financial services and that most of those without access to financial services dwell in rural areas (CBN, 2005). Microfinance has been described as a development tool used to create access for the economically active poor to financial services at an affordable price (CBN, 2011). It is the provision of credit and other financial services to the lowincome group and micro entrepreneurs to enable them build sustainable microenterprises (Otero, 2000; Nkamnebe, 2008; and Muktar, 2009). In a study carried out by Oni, Paiko and Ormin (2012), it was found that $70.22 \%$ of the samples have regular access to MFIs services, $8.89 \%$ have irregular access to microfinance services and $83.89 \%$ have no access to MFI services. They conclude that access to MFI services by SMEs is poor.

\section{Theoretical Framework}

The theoretical framework for this study is grounded in the structure of the neoclassical CobbDouglass production function but based on the principle of the Stimulus-Organism-Response model otherwise known as the Black box model (Bagozzi, 1986; Blagoev, 2003) or the Reinforcement model ( East, Wright and Vanhuele, 2013). The model has its origin in cognitive psychology, the mental structures and processes which mediate between stimulus and response (Kihlstron, 1987). A wide range of factors are fundamental to the intrapersonal processes responsible for response. These include perception, learning, memory, thinking, emotion and motivation (Sternberg, 1996). Early Stimulus - Organism-Response models suggest a linear relationship between the three stages with environmental and social stimuli acting as external antecedents to the organism. This approach assumes that stimuli act upon an inactive and unprepared organism (Eysenk and Keane,
2000). The model presents how customers' personal characteristics, the interpersonal and intrapersonal stimuli, and the consumers' responses interact with each other (Evans et al., 2013).Therefore, the relevance of this theory rests on the intrapersonal processes of stimulus (SSEs perception) and organism (MFBs) that are responsible for response (SSEs performance). In this study, organism is assumed (MFBs) to act as Reinforcement. The theory stipulates that the interaction of the input variables (stimulus) and the intervening variables (organism) determine the level of involvement in productive activities (response).

By formular the theory can be expressed as:

Organisation Productive Activities (OPA) $=\mathrm{f}(\mathrm{In}-$ put variable + Intervening variable)--------(i)

Response $=$ Stimulus + Organism ............. (ii)

Charles Cobb and Paul Douglas in 1928 considered a simple economy in which production output is determined by the amount of labour involved and the amount of capital invested, while there many other factors affecting economic performance, their production model was of this form: $Y=$

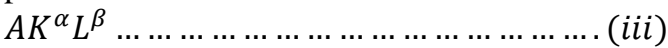

Where:

$\mathrm{Y}=$ total production (the monetary value of all goods produced in a year)

$\mathrm{L}=$ labor input (the total number of personhours worked in a year)

$\mathrm{K}=$ capital input (the monetary worth of all machinery, equipment, and buildings)

$\mathrm{A}=$ total factor productivity

$\alpha$ and $\beta$ are the output elasticities of capital and labour respectively. These values are constantly determined by available technology. Output elasticity measures the responsiveness of output to a change in levels of either labour or capital used in production, ceteris paribus.

In the Cobb-Douglas function, " $\alpha$ " is the output elasticity of capital which measures the responsiveness of output to a unit change in capital and it is the stimulus in the present model while " $\mathrm{Y}$ " which represents total production in Cobb-Douglas function is the response variable in the Stimulus Organism-Response model.

If we $\log$ linearized equation (1)

$\operatorname{In} Y=\operatorname{In} A+\alpha \operatorname{In} K+\beta \operatorname{In} L$

Equation (iv) expresses productivity (Y) as a linear function of capital $(\mathrm{K})$ input, which has provided theoretical premise for the core analysis of the study in the spirit of Stimulus - OrganismResponse model between the productivity of the SSEs and the microcredit loans and other banking services from MFBs.

\section{Methodology}

Research Design. Descriptive survey design was employed to investigate into intricacies of what actually transpire between SSEs and the micro- 
finance bank products accessibility in Osun State. The study also adopted econometric method to determine the influence of microfinance bank product accessibility on the performance of SSEs in Osun State. Specifically, Ordinary Least Square (OLS) analytical technique was used. This study adopted ordinary least square because the technique produces unbiased and consistent estimate.

Area of the study: This study was carried out in Osun State of Nigeria.

Population for the study: Population for the study consisted of thirty (30) microfinance banks in Osun State as at $31^{\text {st }}$ December, 2014 and One thousand four hundred small scale enterprises that registered with Osogbo chapter of Nigerian association of small scale industries as $31^{\text {st }}$ December, 2013.

Sample size and sampling techniques: 90 management staff of the 30 microfinance banks in Osun State and four hundred and sixty five small scale enterprises was sampled using purposive and simple random sampling techniques respectively.

\section{Model Specification}

The empirical analysis in this sub-section of the study was based on the theoretical relationship between entrepreneurial performance and the microfinance bank activities in terms of financial product

$$
\text { sales }_{i}=\beta_{0}+\sum_{k=1}^{n} \beta_{i} F P_{k}+\varepsilon_{1 i}
$$

Where,

Sales $=$ is average monthly sales.

$F P=$ is a vector of microfinance bank financial products variables which include accounts, loans,

$$
\text { total asset }_{i}=\gamma_{0}+\sum_{k=1}^{n} \gamma_{i} F P_{k}+\varepsilon_{1}
$$

Where,

Total Asset $=$ represents present total capital.

$F P=$ is a vector of microfinance bank financial products variables which include accounts, loans,

$$
E m p_{i}=\theta_{0}+\sum_{k=1}^{n} \theta_{i} F P_{k}+\varepsilon_{1 i}
$$

Where,

Emp $=$ number of employees.

$F P=$ is a vector of microfinance bank financial products variables which include accounts, loans,

$$
\text { profit }_{i}=\pi_{0}+\sum_{k=1}^{n} \pi_{i} F P_{k}+\varepsilon_{1}
$$

Where, Profit $=$ average monthly profit.

$F P=$ is a vector of microfinance bank financial products variables which include accounts, loans, daily contribution, assets financing, cheque discounting, funds transfer, micro insurance and financial advisory. accessibility with a view to evaluating the influence of microfinance banks activities on the performance of the small scale enterprises in Osun State. The empirical model was developed from the works of Asaolu (2004), Babajide (2011) and Babajide (2012). Asaolu (2004) examined performance evaluation of cooperative investment and credit society in financing small scale enterprises; Babajide (2011) examined the effects of microfinance bank health services on micro and small enterprises and Babajide (2012) examined the effects of microfinance on micro and small enterprises growth in Nigeria. The model specification is specified as:

$P F=f(F P)$

Where, ' $P F$ ' represents performance of the SSEs ' $F P$ ' represents microfinance bank financial products accessed by SSEs.

Equation (v) presents the functional relationship between SSEs' performance and MFB financial products accessed by SSEs. From the equation, performance consists of four measures (sales, total assets, number of employees and profit) and MFB financial products component include accounts, loans, daily contribution, assets financing, cheque discounting, funds transfer, micro insurance and financial advisory.

The above equation can be re-specified in an explicit form as shown below:

daily contribution, assets financing, cheque discounting, funds transfer, micro insurance and financial advisory. 
entrepreneurs, the extent to which microfinance banks have influenced the performance of small scale enterprises in the study area and assess the problems encountered by Microfinance Bank Operators in financing SSEs
Financial Products Developed by Nigerian Microfinance Banks Specifically for Small Scale Enterprises (SSEs)

Responses of the participants (MFB operators) on MFB's financial products were analysed and presented in Table 1.

Table 1: Availability of MFB Financial Products in Osun State, Nigeria

\begin{tabular}{|c|c|c|c|c|c|c|c|c|c|}
\hline & & Availability & & If avail & , to what & tent are & y accessed by & SSEs & \\
\hline Variables & No & Yes & Total & $\begin{array}{l}\text { Highly } \\
\text { Accessible }\end{array}$ & $\begin{array}{l}\text { Acces- } \\
\text { sible }\end{array}$ & $\begin{array}{l}\text { Unde- } \\
\text { cided }\end{array}$ & $\begin{array}{l}\text { Fairly } \\
\text { Accessible }\end{array}$ & $\begin{array}{l}\text { Not } \\
\text { Acces- } \\
\text { sible }\end{array}$ & $\begin{array}{l}\text { Mean } \\
\text { rank }\end{array}$ \\
\hline $\begin{array}{l}\text { Savings ac- } \\
\text { count }\end{array}$ & $3(3.8)$ & $75(96.2)$ & $78(100)$ & $64(82.1)$ & $11(14.1)$ & & & & 4.85 \\
\hline Current account & $4(5.1)$ & $74(94.9)$ & $78(100)$ & $63(80.8)$ & $11(14.1)$ & & & & 4.85 \\
\hline Business loan & $1(1.3)$ & $77(98.7)$ & $78(100)$ & $33(42.3)$ & $43(55.1)$ & $1(1.3)$ & & & 4.42 \\
\hline Asset loan & $20(25.6)$ & $58(74.4)$ & $78(100)$ & $29(37.2)$ & $20(25.6)$ & & $9(11.5)$ & & 4.19 \\
\hline $\begin{array}{l}\text { Local purchase } \\
\text { order }\end{array}$ & $43(55.1)$ & $35(44.9)$ & $78(100)$ & $14(17.9)$ & $18(23.1)$ & & $3(3.8)$ & & 4.23 \\
\hline $\begin{array}{l}\text { Daily contribu- } \\
\text { tions }\end{array}$ & $14(17.9)$ & $64(82.1)$ & $78(100)$ & $46(59)$ & $18(23.1)$ & & & & 4.72 \\
\hline Import finance & $70(89.7)$ & $8(10.3)$ & $78(100)$ & $1(1.3)$ & $5(6.4)$ & & $1(1.3)$ & $1(1.3)$ & 3.50 \\
\hline $\begin{array}{l}\text { Joint associa- } \\
\text { tion account }\end{array}$ & $25(32.1)$ & $53(67.9)$ & $78(100)$ & $24(30.8)$ & $24(30.8)$ & & $4(5.1)$ & $1(1.3)$ & 4.25 \\
\hline $\begin{array}{l}\text { Cooperative } \\
\text { loan }\end{array}$ & $15(19.2)$ & $63(80.8)$ & $78(100)$ & $29(37.2)$ & $29(37.2)$ & $1(1.3)$ & $3(3.8)$ & $1(1.3)$ & 4.30 \\
\hline $\begin{array}{l}\text { Term deposit } \\
\text { account }\end{array}$ & $15(19.2)$ & $63(80.8)$ & $78(100)$ & $35(44.9)$ & $20(25.6)$ & $3(3.8)$ & $4(5.1)$ & $1(1.3)$ & 4.33 \\
\hline Overdraft & $12(15.4)$ & $66(84.6)$ & $78(100)$ & $45(57.7)$ & $15(19.2)$ & & $5(6.4)$ & $1(1.3)$ & 4.48 \\
\hline $\begin{array}{l}\text { Emergency } \\
\text { loan }\end{array}$ & $24(30.8)$ & $54(69.2)$ & $78(100)$ & $22(28.2)$ & $22(28.2)$ & $3(3.8)$ & $7(9)$ & & 4.09 \\
\hline $\begin{array}{l}\text { Equipment } \\
\text { leasing }\end{array}$ & $45(57.7)$ & $33(42.3)$ & $78(100)$ & $9(11.5)$ & $10(12.8)$ & $3(3.8)$ & $10(12.8)$ & $1(1.3)$ & 3.48 \\
\hline $\begin{array}{l}\text { Fixed asset } \\
\text { loan }\end{array}$ & $35(44.9)$ & $43(55.1)$ & $78(100)$ & 14(17.9) & $16(20.5)$ & $1(1.3)$ & $8(10.3)$ & $4(5.1)$ & 3.65 \\
\hline $\begin{array}{l}\text { Working capi- } \\
\text { tal loan }\end{array}$ & $21(26.9)$ & $57(73.1)$ & $78(100)$ & $25(32.1)$ & $21(26.9)$ & $2(2.6)$ & $4(5.1)$ & $5(6.4)$ & 4.00 \\
\hline $\begin{array}{l}\text { Hire purchase } \\
\text { financing }\end{array}$ & $45(57.7)$ & $33(42.3)$ & $78(100)$ & $16(20.5)$ & $9(11.5)$ & & $5(6.4)$ & $3(3.8)$ & 3.91 \\
\hline Fixed deposit & $15(19.2)$ & $63(80.8)$ & $78(100)$ & $38(48.7)$ & $22(28.2)$ & & $3(3.8)$ & & 4.51 \\
\hline $\begin{array}{l}\text { Financial advi- } \\
\text { sory service }\end{array}$ & $29(37.2)$ & $49(62.8)$ & $78(100)$ & $22(28.2)$ & $22(28.2)$ & $1(1.3)$ & $3(3.8)$ & $1(1.3)$ & 4.24 \\
\hline Funds transfer & $22(28.2)$ & $56(71.8)$ & $78(100)$ & $31(39.7)$ & $18(23.1)$ & $3(3.8)$ & $2(2.6)$ & $2(2.6)$ & 4.32 \\
\hline $\begin{array}{l}\text { Micro-lease } \\
\text { arrangement }\end{array}$ & $48(61.5)$ & $30(38.5)$ & $78(100)$ & $10(12.8)$ & $9(11.5)$ & $5(6.4)$ & $4(5.1)$ & $2(2.6)$ & 3.70 \\
\hline $\begin{array}{l}\text { Safe keeping of } \\
\text { valuables }\end{array}$ & $43(55.1)$ & $35(44.9)$ & $78(100)$ & $9(11.5)$ & $14(17.9)$ & & $9(11.5)$ & $3(3.8)$ & 3.49 \\
\hline $\begin{array}{l}\text { Cheque dis- } \\
\text { counting }\end{array}$ & $44(56.4)$ & $34(43.6)$ & $78(100)$ & $13(16.7)$ & $8(10.3)$ & $1(1.3)$ & $8(10.3)$ & $4(5.1)$ & 3.53 \\
\hline $\begin{array}{l}\text { Execution of } \\
\text { standing orders }\end{array}$ & $27(34.6)$ & $51(65.4)$ & $78(100)$ & $23(29.5)$ & $15(19.2)$ & $1(1.3)$ & $7(9)$ & $5(6.4)$ & 3.86 \\
\hline $\begin{array}{l}\text { Treasury man- } \\
\text { agement }\end{array}$ & $43(55.1)$ & $35(44.9)$ & $78(100)$ & $17(21.8)$ & $10(12.8)$ & $1(1.3)$ & $5(6.4)$ & $2(2.6)$ & 4.00 \\
\hline Asset finance & $38(48.7)$ & $40(51.3)$ & $78(100)$ & $10(12.8)$ & $17(21.8)$ & $2(2.6)$ & $6(7.7)$ & $5(6.4)$ & 3.53 \\
\hline $\begin{array}{l}\text { Micro- } \\
\text { insurance ser- } \\
\text { vices }\end{array}$ & $35(44.9)$ & $43(55.1)$ & $78(100)$ & $4(5.1)$ & $22(28.2)$ & $3(3.8)$ & $7(9)$ & $7(9)$ & 3.21 \\
\hline
\end{tabular}

Source: Field survey, 2015

Table 1 presented the views of the respondents (MFB operators) whether the MFB financial products were available, and if they were available, the extent to which they were accessed by SSEs. From the table, the operators believed that business loan was the most available financial product to customers, followed by savings account and current account. This study revealed that the least available financial product to customers was import finance. This implies that microfinance banks provided loan facilities to the SSEs owners in Osun State. The result confirmed the view of Ojo (2009) that microfinance institutes were set up to give out loans and other credit assistance to SSEs. In addition, the table revealed savings account and current account as the most available and accessible financial products 
with a mean of 4.85 out of 5 while business loan had a mean of 4.42 as the second available and accessible financial product to SSEs from MFB operators' view. To bank officials, all the twenty four products were made available to SSEs.

\section{Accessibility of the Microfinance Bank Facilities to Small Scale Enterprises in Osun State}

Whenever the issue of microfinance banks and the SSEs is raised, one of the things that first come to mind is the issue of accessibility. According to Barnes, Morris and Gaile (1999), widespread recognition of low accessibility to formal credit has led to recent endeavors to target the poor, especially women entrepreneurs, through development programmes that provide financial services. Microfinance by definition is an attempt to help the poor or the low income earners who cannot on their own raise the required capital however little to start business so as to be able to engage themselves as self-employed thereby promoting productivity and growth of the economy at large. So, if the microfinance banks loans are not easily accessible to the SSEs operators, it will be difficult for the microfinance banks to impact on the poor. One of the ways to avoid the financial assistance being offered by the bank from being high jacked by the rich people is to avoid attaching stringent conditions and process to the access of the loans. To answer this question, responses of the participants (SSEs owners) on MFB financial products awareness, level of satisfaction and accessibility were analysed and the results were as presented in Tables 2, 3 and 4 respectively.

Table 2: Awareness of MFB Financial Products

\begin{tabular}{llll}
\hline Financial PRODUCTS & Yes & No & Total \\
\hline Savings account & $368(98.7)$ & $5(1.3)$ & $373(100)$ \\
Current account & $344(92.2)$ & $29(7.8)$ & $373(100)$ \\
Joint association Account & $142(38.1)$ & $231(61.9)$ & $373(100)$ \\
Business loan & $299(80.2)$ & $74(19.8)$ & $373(100)$ \\
Term deposit account & $237(63.5)$ & $136(36.5)$ & $373(100)$ \\
Emergency loan & $189(50.7)$ & $184(49.3)$ & $373(100)$ \\
Fixed asset loan & $168(45.0)$ & $205(55.0)$ & $373(100)$ \\
Overdraft & $266(71.3)$ & $107(28.7)$ & $373(100)$ \\
Cooperative loan & $284(76.1)$ & $89(23.9)$ & $373(100)$ \\
Working capital loan & $277(74.3)$ & $96(25.7)$ & $373(100)$ \\
Micro-insurance services & $71(19)$ & $302(81)$ & $373(100)$ \\
Financial advisory service & $176(47.2)$ & $197(52.8)$ & $373(100)$ \\
Hire purchase financing & $137(36.7)$ & $236(63.3)$ & $373(100)$ \\
Import financing & $52(13.9)$ & $321(86.1)$ & $373(100)$ \\
Local purchase order financing & $74(19.8)$ & $299(80.2)$ & $373(100)$ \\
Asset finance & $189(50.7)$ & $184(49.3)$ & $373(100)$ \\
Equipment leasing & $53(14.2)$ & $320(85.8)$ & $373(100)$ \\
Micro-lease arrangement & $72(19.3)$ & $301(80.7)$ & $373(100)$ \\
Funds transfer & $142(38.1)$ & $231(61.9)$ & $373(100)$ \\
Daily contribution & $237(63.5)$ & $136(36.5)$ & $373(100)$ \\
Safe keeping of valuables & $100(26.8)$ & $273(73.2)$ & $373(100)$ \\
Cheque discounting & $218(58.4)$ & $155(41.6)$ & $373(100)$ \\
Execution of standing orders & $106(28.4)$ & $267(71.6)$ & $373(100)$ \\
Treasury management & $83(22.3)$ & $290(77.7)$ & $373(100)$ \\
\hline
\end{tabular}

Source: Field survey, 2015

Table 2 revealed that over $50 \%$ of the respondents agreed that SSEs were aware of the following products: savings account, current account, business loan, cooperative loan, working capital loan, overdraft, daily contribution, term deposit account, cheque discounting, asset finance and emergency loan. 
Table 3: Level of Satisfaction on MFB Financial Products

\begin{tabular}{|c|c|c|c|c|c|c|c|}
\hline Variables & $\begin{array}{l}\text { Very Satis- } \\
\text { factory }\end{array}$ & $\begin{array}{l}\text { Just Satis- } \\
\text { factory }\end{array}$ & $\begin{array}{l}\text { Neither satis- } \\
\text { factory nor } \\
\text { unsatisfactory }\end{array}$ & $\begin{array}{c}\text { Satisfactory } \\
\text { with reser- } \\
\text { vations } \\
\end{array}$ & $\begin{array}{l}\text { Not satis- } \\
\text { factory }\end{array}$ & Total & $\begin{array}{l}\text { Mean } \\
\text { rank }\end{array}$ \\
\hline Savings account & $262(70.2)$ & $70(18.8)$ & $22(5.9)$ & $19(5.1)$ & & $373(100)$ & 4.54 \\
\hline Current account & $169(45.3)$ & $71(19)$ & $126(33.8)$ & $7(1.9)$ & & $373(100)$ & 4.06 \\
\hline Business loan & $146(39.1)$ & $46(12.3)$ & $158(42.4)$ & $14(3.8)$ & $9(2.4)$ & $373(100)$ & 3.82 \\
\hline Asset Loan & $96(25.7)$ & $40(10.7)$ & $226(60.6)$ & $3(0.8)$ & $8(2.1)$ & $373(100)$ & 3.57 \\
\hline $\begin{array}{l}\text { Local Purchase Order Financ- } \\
\text { ing }\end{array}$ & $39(10.5)$ & $36(9.7)$ & $275(73.7)$ & $7(1.9)$ & $16(4.3)$ & $373(100)$ & 3.20 \\
\hline Daily Contribution & 174(46.6) & $17(4.6)$ & $166(44.5)$ & $5(1.3)$ & $11(2.9)$ & $373(100)$ & 3.91 \\
\hline Import Finance & $36(9.7)$ & $26(7)$ & $269(72.1)$ & $8(2.1)$ & $34(9.1)$ & $373(100)$ & 3.06 \\
\hline Joint Association Account & $45(12.1)$ & $23(6.2)$ & $271(72.7)$ & $8(2.1)$ & $26(7)$ & $373(100)$ & 3.14 \\
\hline Cooperative Loan & $148(39.7)$ & $33(8.8)$ & $166(44.5)$ & $8(2.1)$ & $18(4.8)$ & $373(100)$ & 3.76 \\
\hline Term Deposit Account & $42(11.3)$ & $37(9.9)$ & 267(71.6) & $3(0.8)$ & $24(6.4)$ & $373(100)$ & 3.19 \\
\hline Overdraft & $78(20.9)$ & $23(6.2)$ & $260(69.7)$ & $7(1.9)$ & $5(1.3)$ & $373(100)$ & 3.43 \\
\hline Emergency Loan & $65(17.4)$ & $23(6.2)$ & $268(71.8)$ & $8(2.1)$ & $9(2.4)$ & $373(100)$ & 3.34 \\
\hline Equipment Leasing & $31(8.3)$ & $26(7)$ & $283(75.9)$ & $14(3.8)$ & $19(5.1)$ & $373(100)$ & 3.10 \\
\hline Fixed asset loan & $40(10.7)$ & $27(7.2)$ & $277(74.3)$ & $9(2.4)$ & $20(5.4)$ & $373(100)$ & 3.16 \\
\hline Working capital loan & $61(16.4)$ & $25(6.7)$ & $259(69.4)$ & $13(3.5)$ & $15(4)$ & $373(100)$ & 3.28 \\
\hline Hire purchase financing & 42(11.3) & $26(7)$ & $271(72.7)$ & $11(2.9)$ & $23(6.2)$ & $373(100)$ & 3.14 \\
\hline Fixed deposit & $45(12.1)$ & $24(6.4)$ & $270(72.4)$ & $9(2.4)$ & $25(6.7)$ & $373(100)$ & 3.15 \\
\hline Financial advisory service & $36(9.7)$ & $20(5.4)$ & $275(73.7)$ & $10(2.7)$ & $32(8.6)$ & $373(100)$ & 3.05 \\
\hline Funds transfer & $39(10.5)$ & $26(7)$ & $274(73.5)$ & $8(2.1)$ & $26(7)$ & $373(100)$ & 3.12 \\
\hline Micro-lease arrangement & $31(8.3)$ & $27(7.2)$ & $282(75.6)$ & $1(0.3)$ & $32(8.6)$ & $373(100)$ & 3.06 \\
\hline Safe keeping of valuables & $45(12.1)$ & $27(7.2)$ & $274(73.5)$ & $7(1.9)$ & $20(5.4)$ & $373(100)$ & 3.19 \\
\hline Cheque discounting & $44(11.8)$ & $28(7.5)$ & 267(71.6) & $6(1.6)$ & $28(7.5)$ & $373(100)$ & 3.14 \\
\hline Execution of standing orders & $29(7.8)$ & $26(7)$ & $281(75.3)$ & $5(1.3)$ & $32(8.6)$ & $373(100)$ & 3.04 \\
\hline Treasury management & $27(7.2)$ & $25(6.7)$ & $279(74.8)$ & $6(1.6)$ & $36(9.7)$ & $373(100)$ & 3.00 \\
\hline Asset finance & $32(8.6)$ & $24(6.4)$ & $279(74.8)$ & $6(1.6)$ & $32(8.6)$ & $373(100)$ & 3.05 \\
\hline Micro-insurance services & $37(9.9)$ & $21(5.6)$ & $275(73.7)$ & $3(0.8)$ & $37(9.9)$ & $373(100)$ & 3.05 \\
\hline
\end{tabular}

Table 3 revealed that SSEs were very satisfied with savings account, current account, daily contribution, business loan, cooperative loan and asset loan with mean rank values of $4.54,4.06,3.91,3.82,3.72$, and 3.57 out of 5 respectively.

Table 4: Degree of MFBs Financial Products Accessibility

\begin{tabular}{|c|c|c|c|c|c|}
\hline & Yes $(\%)$ & No $(\%)$ & Total $(\%)$ & Year & Average Value \\
\hline Savings Account & $343(92.0)$ & $30(8.0)$ & $373(100)$ & 6 & 379015.27 \\
\hline Current Account & $202(54.2)$ & $171(45.8)$ & $373(100)$ & 6 & 1117392.86 \\
\hline Business Loan & $195(52.3)$ & $178(47.7)$ & $373(100)$ & 5 & 566821.72 \\
\hline Asset Loan & $85(22.8)$ & $288(77.2)$ & $373(100)$ & 6 & 477872.34 \\
\hline Local purchase Order Financing & $24(6.4)$ & $349(93.6)$ & $373(100)$ & 5 & 250083.33 \\
\hline Daily Contribution & $170(45.6)$ & $203(54.4)$ & $373(100)$ & 5 & 262256.00 \\
\hline Import Finance & $180(48.3)$ & $193(51.7)$ & $373(100)$ & 4 & 1055000.00 \\
\hline Joint Association Account & $39(10.5)$ & $334(89.5)$ & $373(100)$ & & \\
\hline Cooperative Loan & $158(42.4)$ & $215(57.6)$ & $373(100)$ & 4 & 466725.49 \\
\hline Term Deposit Account & $41(11.0)$ & $332(89.0)$ & $373(100)$ & 2 & 295000.00 \\
\hline Overdraft & $84(22.5)$ & $289(77.5)$ & $373(100)$ & 6 & 433077.04 \\
\hline Emergency Loan & $68(18.2)$ & $305(81.8)$ & $373(100)$ & 6 & 124687.50 \\
\hline Equipment Leasing & $25(6.7)$ & $348(93.3)$ & $373(100)$ & 3 & 766666.67 \\
\hline Fixed Asset Loan & $33(8.8)$ & $340(91.2)$ & $373(100)$ & 5 & 1133333.33 \\
\hline Working capital Loan & $54(14.5)$ & $319(85.5)$ & $373(100)$ & 5 & 207200.00 \\
\hline Hire Purchase Financing & $35(9.4)$ & $338(90.6)$ & $373(100)$ & 4 & 350000.14 \\
\hline Fixed Deposit & $46(12.3)$ & $327(87.7)$ & $373(100)$ & 2 & 1390000.00 \\
\hline Financial Advisory Service & $34(9.1)$ & $339(90.9)$ & $373(100)$ & 3 & 100000.00 \\
\hline Funds Transfer & $29(7.8)$ & $344(92.2)$ & $373(100)$ & 3 & 126666.67 \\
\hline Micro-lease Arrangement & $25(6.7)$ & $348(93.3)$ & $373(100)$ & 3 & \\
\hline Safe Keeping of Variables & $33(8.8)$ & $340(91.2)$ & $373(100)$ & 2 & 23334.67 \\
\hline Cheque Discounting & $60(16.1)$ & $313(83.9)$ & $373(100)$ & 6 & 50000.00 \\
\hline Execution of Standing Orders & $24(6.4)$ & $349(93.6)$ & $373(100)$ & 3 & 650000.00 \\
\hline Treasury Management & $22(5.9)$ & $351(94.1)$ & $373(100)$ & 2 & 500000.00 \\
\hline Asset Finance & $22(5.9)$ & $351(94.1)$ & $373(100)$ & 2 & 2000000.00 \\
\hline Micro-insurance Services & $24(6.4)$ & $349(93.6)$ & $373(100)$ & 4 & 1000000.50 \\
\hline
\end{tabular}


From the findings of this study, Table 2 showed that the SSEs were mostly aware of MFB savings account, followed by current account and they were least aware of MFBs' import financing. Table 3 presented the level of satisfaction of SSEs on MFBs' financial products. The study revealed that savings account had the highest mean rank value which is 4.5 out of 5.0, followed by current account (with mean value of 4.06). This implies that the SSEs were very satisfied using savings account and current account. The study also revealed treasury management as the least satisfaction financial product. On the accessibility of the financial products, Table 5 revealed savings accounts as the most accessible product $(92 \%)$, followed by current account $(54.2 \%)$ and business loan $(52.3 \%)$. But the least accessible financial products were treasury man- agement and asset finance. In summary, from SSEs' point of view, only three products out of twentyfour products of MFBs were accessible to SSEs, meaning that majority of the bank products was not accessible. The finding in this study corroborates the view of Jamil (2008) that micro entrepreneurs are denied access to financial services. In addition, the finding of this study agreed with the CBN (2005) observation that only $35 \%$ of Nigerians had access to financial services. However, the finding of this study disagreed with Oni, Paiko and Ormin (2012) who found that $70.22 \%$ of SSEs sampled had regular access to MFIs services.

When financial products were regrouped from twenty-four MFB products into eight products, Tables 2 and 4 became Tables 5 and 7 .

Table 5: Awareness of Regrouped MFB Financial Products

\begin{tabular}{llrr}
\hline Variables & YES & NO & TOTAL \\
\hline Accounts & $73.12 \%$ & $26.88 \%$ & $100.0 \%$ \\
Loans & $66.26 \%$ & $33.74 \%$ & $100.0 \%$ \\
Daily Contribution & $63.53 \%$ & $36.46 \%$ & $100.0 \%$ \\
Assets Finance & $25.78 \%$ & $74.22 \%$ & $100.0 \%$ \\
Cheque Discounting & $58.44 \%$ & $41.55 \%$ & $100.0 \%$ \\
Funds Transfer & $33.24 \%$ & $66.75 \%$ & $100.0 \%$ \\
Micro insurance & $22.92 \%$ & $77.07 \%$ & $100.0 \%$ \\
Financial Advisory & $34.71 \%$ & $65.28 \%$ & $100.0 \%$ \\
\hline
\end{tabular}

Table 6: Level of Satisfaction on Regrouped MFBs Financial Products

\begin{tabular}{|c|c|c|c|c|c|c|}
\hline Variables & $\begin{array}{c}\text { Very } \\
\text { satisfactory }\end{array}$ & $\begin{array}{c}\text { Just } \\
\text { satisfactory }\end{array}$ & $\begin{array}{l}\text { Neither satisfactory } \\
\text { nor unsatisfactory }\end{array}$ & $\begin{array}{l}\text { Satisfactory } \\
\text { with reserva- } \\
\text { tion }\end{array}$ & $\begin{array}{l}\text { Not Satisfac- } \\
\text { tory }\end{array}$ & Total \\
\hline Accounts & 5.17 & 2.29 & 50.94 & 11.74 & 29.86 & 100.00 \\
\hline Loans & 5.32 & 4.58 & 56.59 & 9.77 & 23.75 & 100.00 \\
\hline Daily & 2.94 & 1.34 & 44.5 & 4.55 & 46.64 & 99.97 \\
\hline Contribution & & & & & & \\
\hline $\begin{array}{l}\text { Assets Financ- } \\
\text { ing }\end{array}$ & 6.97 & 2.10 & 74.13 & 7.37 & 9.43 & 100.00 \\
\hline $\begin{array}{l}\text { Cheque Dis- } \\
\text { counting }\end{array}$ & 7.50 & 1.60 & 71.58 & 7.50 & 11.79 & 99.97 \\
\hline Funds Transfer & 7.77 & 1.74 & 74.40 & 6.97 & 9.12 & 100.00 \\
\hline Micro Insurance & 7.64 & 1.34 & 73.59 & 6.43 & 10.99 & 100.00 \\
\hline $\begin{array}{l}\text { Financial Advi- } \\
\text { sory Service }\end{array}$ & 9.12 & 2.14 & 74.26 & 6.03 & 8.45 & 100.00 \\
\hline
\end{tabular}

Table 7: Degree of Regrouped MFB Financial Products Accessibility

\begin{tabular}{llll}
\hline Variables & \multicolumn{1}{c}{ YES $(\%)$} & NO $(\%)$ & TOTAL $(\%)$ \\
\hline Account & $273(73.12)$ & $100(26.87)$ & $373(100)$ \\
Loans & $247(66.26)$ & $126(33.73)$ & $373(100)$ \\
Daily contribution & $237(63.53)$ & $136(36.46)$ & $373(100)$ \\
Assets Financing & $96(25.78)$ & $277(74.21)$ & $373(100)$ \\
Cheque Discounting & $218(58.44)$ & $155(41.55)$ & $373(100)$ \\
Funds Transfer & $124(33.24)$ & $249(66.75)$ & $373(100)$ \\
Micro insurance & $86(22.92)$ & $287(77.07)$ & $373(100)$ \\
Financial Advisory Service & $130(34.71)$ & $243(65.28)$ & $373(100)$ \\
\hline
\end{tabular}


Figures 4.6 and 4.7 depicted the following financial products as being known to the SSEs and accessible by them: maintenance of accounts, loan, daily contribution and cheque discounting. The study revealed maintenance of accounts as the most accessible.

\section{Testing of Hypotheses}

$\mathrm{HO}_{\mathrm{I}}$ : Microfinance bank financial products accessibility perception does not significantly affect the SSEs' performance
For Hypothesis One, regression analysis was also employed to examine the relationship between the independent variable (financial products accessibility perception) and dependent variables (SSEs performance indicators of total capital, number of employees, sales, and profit and aggregate performance). Table 8 presented the summary of the results.

Table 8: Influence of MFB Financial Products Accessibility Perception on SSEs Performance Indicators

\begin{tabular}{|c|c|c|c|c|c|c|c|c|c|c|c|c|}
\hline \multirow[t]{2}{*}{ Variables } & \multicolumn{3}{|c|}{ Total capital } & \multicolumn{3}{|c|}{ Number of Employees } & \multicolumn{3}{|c|}{ Sales } & \multicolumn{3}{|c|}{ Profit } \\
\hline & B & $\mathrm{T}$ & $\mathrm{p}-\mathrm{v}$ & $\beta$ & $\mathrm{T}$ & $\mathrm{p}-\mathrm{v}$ & $\beta$ & $\mathrm{T}$ & $\mathrm{p}-\mathrm{v}$ & $\beta$ & $\mathrm{T}$ & $p-v$ \\
\hline Accounts & .357 & 1.99 & 0.04 & .358 & 1.5 & .124 & .190 & .97 & .328 & -.06 & -.32 & .744 \\
\hline Loans & -.039 & -735 & .463 & -.032 & -.47 & .638 & -.146 & -2.5 & .011 & -.04 & -.90 & .368 \\
\hline $\begin{array}{l}\text { Daily con- } \\
\text { tribution }\end{array}$ & $\begin{array}{l}- \\
.320\end{array}$ & $\begin{array}{l}- \\
6.74\end{array}$ & .000 & -.167 & -2.7 & .007 & -.316 & -6.1 & .000 & -.31 & -6.3 & .000 \\
\hline $\begin{array}{l}\text { Assets fi- } \\
\text { nancing }\end{array}$ & .320 & 5.87 & .000 & .090 & 1.5 & .117 & .149 & 3.1 & .002 & .23 & 5.2 & .000 \\
\hline $\begin{array}{l}\text { Cheque } \\
\text { discounting }\end{array}$ & .053 & 1.20 & .230 & .113 & 1.9 & .048 & .159 & 3.3 & .001 & .09 & 1.9 & .048 \\
\hline $\begin{array}{l}\text { Funds trans- } \\
\text { fer }\end{array}$ & -.131 & .281 & .005 & -.152 & -2.5 & .012 & -.177 & -3.5 & .001 & -.12 & -2.6 & .009 \\
\hline $\begin{array}{l}\text { Micro insur- } \\
\text { ance }\end{array}$ & .024 & .442 & .659 & .016 & .22 & .823 & .128 & 2.1 & .032 & .003 & .05 & .960 \\
\hline $\begin{array}{l}\text { Financial } \\
\text { advisory } \\
\text { service }\end{array}$ & .067 & 1.19 & .232 & .017 & .23 & 818 & -.015 & -.25 & .802 & .071 & 1.2 & .222 \\
\hline $\begin{array}{l}\mathrm{R}^{2} \\
\text { Adj. } \mathrm{R}^{2} \\
\text { F- Statistics } \\
\text { p- value }\end{array}$ & $\begin{array}{l}0.283 \\
0.267 \\
17.93 \\
p<.05\end{array}$ & & & $\begin{array}{l}0.083 \\
0.063 \\
4.136 \\
\mathrm{p}<.05 \\
\end{array}$ & & & $\begin{array}{l}0.252 \\
0.235 \\
15.316 \\
p<.05 \\
\end{array}$ & & & $\begin{array}{l}0.27 \\
0.24 \\
15.6 \\
\mathrm{p}<.0\end{array}$ & & \\
\hline
\end{tabular}

Source: Field survey, 2015

Table 8 showed that financial products accessibility perception (accounts, loan, daily contribution, assets financing, cheque discounting, funds transfer, micro insurance and financial advisory service) were joint predictors of total capital $\left(\mathrm{F}_{(8,318)}=17.936 ; \mathrm{p}<.05\right)$. The predictor variables jointly explained $26.7 \%$ of the variance of total capital (Adjusted $\mathrm{R}^{2}=0.267$ ). Furthermore, only accounts $(\beta=0.258, \mathrm{t}=5.874$, $\mathrm{p}<.05)$ and assets financing $(\beta=0.002, \mathrm{t}=3.073$, $\mathrm{p}<.05)$ were significantly independent predictors of capital. This implies that opening of accounts with MFBs and asset financing had significant influence on the total capital employed by SSEs operators.

Table 8 also revealed that financial products (accounts, loans, daily contribution, assets financing, cheque discounting, funds transfer, micro insurance and financial advisory service) jointly had a significant impact on the number of employees engaged by SSEs $\left(\mathrm{F}_{(8,318)}=4.136 ; \mathrm{p}<.05\right)$. The predictor variables (accounts, loans, daily contribution, assets financing, cheque discounting, funds transfer, micro insurance and financial advisory service) jointly contributed $6.3 \%$ to the number of employees engaged by SSEs (Adjusted $\mathrm{R}^{2}=0.063$ ). However, the result revealed that none of the predictor variables independently predicted positively on SSEs number of employees.

Table 8 further showed that financial products (accounts, loans, daily contribution, assets financing, cheque discounting, funds transfer, micro insurance and financial advisory service) were joint predictors of SSEs sales turnover $\left(F_{(8,318)}=15.316\right.$; $\mathrm{p}<.05)$. The predictor variables jointly explained $23.5 \%$ of variance of number of sales turnover (Adjusted $\left.\mathrm{R}^{2}=0.235\right)$. Moreover, assets financing $(\beta=$ $0.149, \mathrm{t}=3.132, \mathrm{p}<.05)$, cheque discounting $(\beta=$ $0.159, \mathrm{t}=3.337, \mathrm{p}<.01)$ and micro insurance $(\beta=$ $0.128, \mathrm{t}=3.120, \mathrm{p}<.05)$ were positive significant independent predictors of sales.

Table 8 also revealed that financial products (accounts, loans, daily contribution, assets financing, cheque discounting, funds transfer, micro insurance and financial advisory service) were joint predictors of profit $\left(\mathrm{F}_{(8,318)}=15.699 ; \mathrm{p}<.05\right)$. The predictor variables jointly explained $24.0 \%$ variance of SSEs profit (Adjusted $\mathrm{R}^{2}=0.240$ ). Furthermore, only assets financing $(\beta=0.239, \mathrm{t}=5.270, \mathrm{p}<.05)$ and cheques discounting $(\beta=0.090, \mathrm{t}=1.982, \mathrm{p}<.05)$ 
were positive significant independent predictors of SSEs profit. The result showed that financial products accessibility perception jointly had a significant impact on SSEs performance indicators. This implies that financial products offered by MFBs have contributed to the growth of SSEs in Osun State.

H02: Microfinance bank financial products accessibility values do not significantly affect the SSES performance
To test Hypothesis two, regression analysis was employed to examine the relationship between the independent variable (MFB products accessibility values) and dependent variables (SSEs performance indicators of total capital, number of employees, sales, and profit). Table 4.20 presented the summary of the results.

Table 9: Influence of MFB Financial Products Accessibility Values on SSEs Performance Indicators

\begin{tabular}{|c|c|c|c|c|c|c|c|c|c|c|c|c|}
\hline \multirow[t]{2}{*}{ Variables } & \multicolumn{3}{|c|}{ Total capital } & \multicolumn{3}{|c|}{ Number of Employees } & \multicolumn{3}{|c|}{ Sales } & \multicolumn{3}{|c|}{ Profit } \\
\hline & $\mathrm{B}$ & $\mathrm{t}$ & $\mathrm{p}-\mathrm{v}$ & $\mathrm{B}$ & $\mathrm{T}$ & $\mathrm{p}-\mathrm{v}$ & $\beta$ & $\mathrm{T}$ & $p-v$ & $\beta$ & $\mathrm{T}$ & $p-v$ \\
\hline Accounts & -.060 & -.99 & .320 & -.006 & -.105 & .917 & -.033 & -.554 & .580 & -.084 & -1.45 & .146 \\
\hline Loans & .177 & 2.81 & .005 & -.088 & -1.40 & .136 & -.004 & -.071 & .944 & .176 & 2.87 & .004 \\
\hline $\begin{array}{l}\text { Daily contri- } \\
\text { bution }\end{array}$ & .061 & .972 & .332 & .123 & 1.92 & .055 & -.072 & -1.11 & .264 & -.191 & -3.04 & .003 \\
\hline $\begin{array}{l}\text { Assets financ- } \\
\text { ing }\end{array}$ & .031 & .470 & .639 & .091 & 1.46 & .144 & -.083 & -1.33 & .184 & -.165 & -2.69 & .007 \\
\hline $\begin{array}{l}\text { Cheque dis- } \\
\text { counting }\end{array}$ & .052 & .809 & .419 & .077 & 1.27 & .203 & -.054 & -.84 & .398 & .028 & .458 & .650 \\
\hline Funds transfer & -.041 & -.634 & .527 & .020 & .318 & .751 & .126 & 1.96 & .051 & -.002 &,- 025 & .980 \\
\hline $\begin{array}{l}\text { Micro insur- } \\
\text { ance }\end{array}$ & -.001 & -.014 & .989 & .016 & .282 & .778 & .090 & 1.48 & .139 & -.009 & -.148 & .883 \\
\hline $\begin{array}{l}\text { Financial ad- } \\
\text { visory service }\end{array}$ & -.106 & -1.54 & -.123 & -.031 & -.478 & .633 & -.172 & -2.57 & .011 & -.125 & -1.91 & .058 \\
\hline $\begin{array}{l}\mathrm{R}^{2} \\
\text { Adj. } \mathrm{R}^{2} \\
\text { F- Statistics } \\
\text { p- Value }\end{array}$ & \multicolumn{3}{|l|}{$\begin{array}{l}0.043 \\
0.015 \\
1.543 \\
p>0.05\end{array}$} & \multicolumn{3}{|c|}{$\begin{array}{l}0.029 \\
0.005 \\
1.207 \\
p>0.05\end{array}$} & \multicolumn{3}{|l|}{$\begin{array}{l}0.055 \\
0.028 \\
2.064 \\
p<.05\end{array}$} & \multicolumn{3}{|l|}{$\begin{array}{l}0.094 \\
0.068 \\
3.691 \\
p<.05\end{array}$} \\
\hline
\end{tabular}

Table 9 showed that financial products accessibility values (accounts, loans, daily contribution, assets financing, cheque discounting, funds transfer, micro insurance and financial advisory service) had no significant impact on total capital with $\left(\mathrm{F}_{(8,318)}=\right.$ 1.543; $\mathrm{p}>0.05)$. However, daily contribution $(\beta=$ $0.061, \mathrm{t}=0.972, \mathrm{p}>0.05)$, and assets financing $(\beta=$ $0.031, \mathrm{t}=0.470, \mathrm{p}>0.05)$ and cheque discounting $(\beta$ $=0.031, \mathrm{t}=0.470, \mathrm{p}>0.05)$ had positive impact on total capital but insignificant, while only loan $(\beta=$ $0.177, \mathrm{t}=2.812, \mathrm{P}<.05)$ had a positive significant impact on total capital.

Table 9 also revealed that financial products accessibility values (accounts, loans, daily contribution, assets financing, cheque discounting, funds transfer, micro insurance and financial advisory service) were not joint predictors of number of employees engaged by $\operatorname{SSEs}$ with $(\mathrm{F}(8,318)=1.207 ; \mathrm{p}>0.05)$. Furthermore, daily contribution $(\beta=0.123, \mathrm{t}=1.925$, $\mathrm{p}>0.05)$, assets financing $(\beta=0.091, \mathrm{t}=1.465$, $p>0.05)$, cheque discounting $(\beta=0.077, t=1.275$, $\mathrm{p}>0.05)$ fund transfer $(\beta=0.020, \mathrm{t}=0.318, \mathrm{p}>0.05)$ and micro insurance $(\beta=0.016, \mathrm{t}=0.282, \mathrm{p}>0.05)$ had a positive impact on the number of employees engaged by SSEs but the impacts were insignificant.

Table 9 also showed that financial products accessibility values (accounts, loans, daily contribution, assets financing, cheque discounting, funds transfer, micro insurance and financial advisory service) had a significant impact on sales with $\left(\mathrm{F}_{(8,318)}=2.064\right.$; $\mathrm{p}<.05)$. The predictor variables explained $2.8 \%$ of variance of sales (Adjusted $\mathrm{R}^{2}=0.028$ ) . Furthermore, only fund transfer $(\beta=0.126, \mathrm{t}=1.956, \mathrm{p}>0.05)$ and micro insurance $(\beta=0.090, \mathrm{t}=1.484, \mathrm{p}>0.05)$ had a positive impact on sales but the impacts were insignificant.

Table 9 also revealed that financial products accessibility values (accounts, loans, daily contribution, assets financing, cheque discounting, funds transfer, micro-insurance and financial advisory service) were joint predictors of profit $\left(\mathrm{F}_{(8,318)}=3.691 ; \mathrm{p}<.05\right)$. The predictor variables explained $6.8 \%$ of variance of profit (Adjusted $\left.\mathrm{R}^{2}=0.068\right)$. Furthermore, loans $(\beta=$ $0.176, \mathrm{t}=2.872, \mathrm{p}<.05)$ were positive significant independent predictor of profit, while cheque discounting $(\beta=0.028, \mathrm{t}=0.455, \mathrm{p}>0.05)$ had a positive impact on profit but the impact was insignificant. The result, therefore, indicated that MFBs financial products accessibility values had partial significant impact on SSEs performance. The study is consistent with Muktar (2009), Banerjee, Duflo and Kinnan (2010), Gaul (2011), Oni, Paiko and Ormin (2012) and Gulani and Usman (2014) that MFBs have not significantly impacted on SSEs in Nigeria. This may be as a result of challenges facing microfinance banks such as frequency of changes in government policy, heavy transaction costs, huge loan losses, low capacity and technical skills in the industry all of which serve as impediments to the growth of the sector. 


\section{Conclusion}

The results revealed that microfinance banks in Osun State offered the same services to the SSEs across the state and their pattern of service delivery is also uniform. However, the microfinance banks services like loans, advisory services assistance, provision of equity capital, etc. were easily accessible to the SSEs.

\section{Recommendations}

Based on the research findings and conclusion, the following policies are recommended for proper development of SSEs' activities in the state. These include;

There should be innovating new products in the microfinance industry in the state different from the conventional products to guide against nonrepayment of loans. There could be new ideas. For instance, if the initial loan sizes are small, the loans should be increased step by step upon successful repayment of each subsequent loan. A customer can start with relatively short loan terms, ranging from 12 weeks to 4 months and subsequent loans amounts could be linked to the amount of mandatory savings in the clients' bank after repayment of the previous loan. This will help to guide against the incidence of non-repayment of loans when the loan and the chargeable interest are not allowed to build up before payment. In addition, this could also help clients to get over the challenge of looking for a viable guarantor before securing a loan.

Microfinance banks should introduce loan products and strategies targeted at financing technology acquisition by SSEs so that all loans will not be directed at trading of goods and services alone. There is the need to widen the technological base of small scale enterprises to foster the development of the real sector of the state economy. In order to encourage technology acquisition, microfinance banks can categorise their loans into low and high interest loans. The conventional loans to clients can be maintained as high interest loans, while loans for capital assets or technology acquisition should be low interest loans, which can be secured by a mortgage over a fixed asset.

Related institutions should be strengthened through reformed policy and legal framework to reduce constraints to SSEs financing. Rules and regulations guiding the microfinance activities should also be enforced. This will undoubtedly reduce the occurrence of loan diversion and nonrepayment of loans that threaten the progress of microfinance activities in the state. There should also be geographic expansion of microfinance operations in the state. The microfinance institutions should move to rural areas while simultaneously expanding clients' bases in urban areas.

\section{References}

Aganga, O. (2012). Nigeria has about 17.3m SMEs. The Nation, 7(2143), 12

Akande, O.O. (2012). Performance analysis of microfinance banks on women entrepreneurs in Oyo State, Nigeria. Research Journal in Organizational Psychology and Educational Studies 1(3), 168-173

Akanji, O. O. (2006). Microfinance as a strategy for poverty reduction. Central Bank of Nigeria Economic and Financial Review, 39 (4), 78-102.

Akiniyi, J. (2009). The role of microfinance empowering women in Africa. Retrieved January 10, 2010 from African Executive Magazine http//www.google.com

Asaolu, T.O. (2004). Evaluation of the performance of the Cooperative Investment and Credit Societies in financing small scale esnterprises (SSEs) in Osun State, Nigeria". Unpublished Ph.D Thesis submitted to Department of Management and Accounting, Obafemi Awolowo University, Ile-Ife.

Babajide, A. (2012). Effects of microfinance on micro and small enterprises (MSEs) growth in Nigeria. Asian Economic and Financial Review 2 (3), 463 - 477.

Babajide, A. A. (2011). Effects of micro financing on micro and small scale enterprises (MSES) in Southwest, Nigeria. Unpublished Ph.D thesis submitted to Department of Banking and Finance, Covenant University, Otta,Nigeria.

Bagozzi, R.P. (1986). Causal Models in Marketing, New York, John Wiley and Sons.

Banerjee, A.E., Duflo, R. and Kinnan, C. (2010). The miracle of microfinance. Evidence from a randomized evaluation. Bureau for Research and Economic Analysis of Development, Working paper 278.

Benerjee, A. and Duflo, E. (2007). The economic lives of the poor. Journal of Economic perspectives 21 (1), 141-167.

Blagoev, V. (2003). Marketing in Bulgaria. Sofia International University

Central Bank of Nigeria (2005). Microfinance policy, regulatory and supervisory framework for Nigeria. (MPRSFN). Abuja, Nigeria.

Cobb, C. W. and Douglas, P.H. (1928). A theory of production. American Economics Review, 139-165

Coleman, B. (2006). Microfinance in North East Thailand: Who benefits and how Much? World Development. 34 (9), 1612-1638.

Coleman, S. (2000). Access to capital and term of credit: A comparison of men and women owned small business. Journal of Small Business Management, 38 (3), $37-53$.

East, R., Wright, M. and Vanhuele, M. (2013). Consumer behaviour. Applications in Marketing. (2nd Ed.). London, Sage.

Gaul, S. (2011). Mapping Africa financial inclusion overview. Washington D. C., microfinance information exchange.

Gulani, M. and Usman, A. (2014). Financing small and medium scale enterprises (SMEs): A challenge for entrepreneur development in Gombe State. Asian Journal of Business and Management Sciences. 2(9), 17-23.

Ibru, C. (2009). Growing microfinance through new technologies, Federal University of Technology, Akure , Nigeria

Iganiga, B.O. (2008). Much ado about nothing: The case of the Nigeria microfinance policy measures, institu- 
tions and operations. Journal of Social Science, $17(2), 89-101$

Iheduru, N.G. (2002). Women entrepreneurship and development. The gendering of microfinance in Nigeria. $8^{\text {th }}$ International Interdisplinary congress on women. Uganda. Makerere University, Kampala.

Jamil, B. (2008). Microfinance as a tool for poverty alleviation in Nigeria. Paper presented at sensitization workshop on microfinance banks in Kano State.

Jegede, C.A., Kehinde, J. and Akinlabi, B. H.(2011). Impact of microfinance on poverty alleviation in $\mathrm{Ni}$ geria: An empirical investigation. European Journal of Humanities and Social Sciences 2(1), 98-111.

Kehinde, O. J. (2006). Poverty alleviation strategies and the challenges of government in Nigeria. The way forward from legion of failed policies, International Journal of Social and Policy Issues, 4(1), 23-39

Kuzilwa, J. (2005). The role of credit for small business success. A study of the National entrepreneurship development fund in Tanzania. Journal of Entrepreneurship. 14 (2), 131 - 161.

Mukatar, M. (2009). The role of microfinance banks in the promotion and development of entrepreneurship in semi urban and rural areas. Journal of Development Economics, 69 ,70-82.

Nkamnebe, A. (2008).Women and micro credit financing in Nigeria: Implications for poverty alleviation and fight against vulnerability. Journal of the Charted Institute of Bankers of Nigeria, October - December.14-30.

Oboh, Y. (2005). The role of Nigeria in relation to banking and industries. A Bullion Publication of CBN 15(2), $23-42$
Ojo, O. (2009). Impact of microfinance on entrepreneurial development. The case of Nigeria. Faculty of Administration and Business, University of Bucharest press.

Okpukppara, B. (2009). Microfinance papers write - up strategies for effective loan delivery to small scale enterprises in rural Nigeria. Journal of Development and Agricultural Economics (2), $41-48$

Onaolapo, A.A and Odetayo, T.A. (2012). Financial inclusion as tools for survival in globally competitive environment: Lesson for Nigerian microfinance banks. American Journal of Business and Management. 1 (4), 241-247.

Ondoro, C.O. and Omena, D. (2012).Effect of microfinance services on the financial empowerment of youth in Migori. Business and Management Review. 2 (3), 22-35.

Oni, E. O., Paiko, I. I. and Ormin, K.(2012).Assessment of the contribution of micro finance institutions (MFIs) to sustainable growth of small and medium scale enterprises (SMEs) in Nigeria. Interdisciplinary Journal of Contemporary Research in Business, 3(9)

Shane, S. (2003). A general theory of entrepreneurship: The Individual-Opportunity Nexus. UK: Edward Elgar.

Sternberg, R. J. (1996). Cognitive psychology. 2nd. Edition, Port Harcourt, Brace College Publishers.

Tarmidi, L.T. (2005). The importance of SMEs in economic development of developing APEC countries. Paper presented at the APEC Study Center Consortium Conference. Jeju, Korea: May 22-25.

Yahaya, K.A., Osemene, O.F. and Abdulraheem, A. (2011). Effectiveness of microfinance banks in alleviating poverty in Kwara State, Nigeria. Global Journal of Management and Business Research. 11(4),12-20. 